811.163.41'366.581

811.163.41'255.4=131.1

821.163.41.08-31 Андрић И.

https://doi.org/10.18485/sj.2018.23.1.22

САША Г. МОДЕРЦ

Универзитет у Београду

Филолошки факултет

ТИЈАНА Н. КУКИТ

Универзитет у Крагујевцу

Филолошко-уметнички факултет
Оригинални научни рад

Примљен: 04. 01. 2018.

Прихваћен: 29. 01. 2018.

\title{
ПРЕЗЕНТ У РОМАНУ „НА ДРИНИ ЋУПРИЈА” И ЮЕГОВА ПРЕВОДИВОСТ НА ИТАЛИЈАНСКИ ЈЕЗИК
}

\begin{abstract}
Превођење дела Иве Андрића на италијански језик поставља низ проблема, међу које спада и адекватно превођење презента. Еластичност којом се презент употребљава у српском омогућује Андрићу изненадне излете у поље субјективно обојеног излагања. Насупрот овоме, ограничења у употреби презента у италијанском језику не дозвољавају да се овај инструмент Андрићеве прозе доследно сачува у преводу. Отуда је српски презент у италијанским преводима често замењен неким прошлим временом, а такав текст губи део психолошких и емотивних конотација које су присутне код Андрића. Разлози за губљење презента у преводу делом су синтаксички, делом су условљени структуром и организацијом италијанског књижевног језика. У неким случајевима изостављање презента представља резултат преводиочеве слободе да се у свом тексту определи за моделе излагања који су доминантни у италијанском језику. У једном моделу доминирају или субјективни или објективни став у излагању, у другом моделу успоставља се опрека између нарације и дескрипције. Ови модели захтевају да се преводилац ограничи на употребу специјализованих глаголских времена, без могућности да у свом тексту прецизно одслика употребе и комбинације српских времена. За српска времена не постоји строго одређена функционална
\end{abstract}

"smoderc@fil.bg.ac.rs 
специјализација у тексту и због тога се она могу међусобно комбиновати с много више слободе него у италијанском језику. Ове структурне разлике између италијанског и српског језика могу да осветле разлоге зашто преводиоци романа На Дрини ћуприја нису увек могли (или нису хтели, у неким случајевима) да у својим преводима доследно сачувају Андрићев презент и конотације које такав презент уноси у текст.

Кључне речи: Иво Андрић, презент италијански, превод, објективност приповедача, психолошко-емотивни став приповедача

Иво Андрић је српски писац који је највише превођен на италијански језик. О интересовању за дела Иве Андрића у Италији сведоче, поред студија и научних чланака, и бројна издања његових романа и приповедака. Детаљан увид у опус Иве Андрића и у преводе његових дела на италијански (и на друге стране језике) објављене до 2011. године доступан је у Библиографији Иве Андрића, коју су приредили Клевернић и др. $(2011)^{1}$. Када је реч о италијанском језику, може се рећи да посебно место заузимају Андрићева сабрана дела, које је 2001. године објавио издавач Мондадори는. Ажурирани подаци о преводима на италијански који су објављени после 2011. године доступни су на сајту Националне библиотеке Италије 3 , у каталозима италијанских интернет књижара (нпр. www.ibs.it) или на сајтовима самих издавача, који преко њих обавештавају читаоце о новим публикацијама. Док је попис превода Андрићевих дела на италијански језик пажљиво допуњаван, текстови самих превода били су у мањој мери предмет анализа; њима није посвећивана одговарајућа пажња, за разлику од књижевне димензије и значаја Андрићевог опуса, који су били предмет интересовања у Италији ${ }^{4}$. Уз ово, не треба заборавити чињеницу да је Андрић неговао посебан однос према Италији ${ }^{5}$. На страну лексичке специфичности Андрићеве прозе, какви су турцизми и изрази везани за локалне појмове и обичаје, који нису познати Италијанима и стога представљају посебан традуктолошки проблем, нарочит изазов у превођењу Андрића представљају ритам и мелодичност његове прозе. Тако, по Секвију (1962: 296), „преводити

${ }^{1}$ Библиографија је доступна и у електронском облику на адреси: http://www.ivoandric.org. rs/библиографија.

${ }^{2}$ Андрићева сабрана дела носе наслов Romanzi e racconti. Издање је једнотомно и обухвата 1524 странице. Предговор је написао Предраг Матвејевић, текстове су превели Дуња Бадњевић и Лионело Костантини. За детаље о овом издању уп. Клевернић и др. (2011: 149, параграф 1164).

${ }^{3} \mathrm{http}: / /$ www.bncrm.librari.beniculturali.it/index.php?it/2/cataloghi.

${ }^{4}$ Можемо сигнализирати, узгредно, следеће студије: Avirović Ljiljana, Il ponte di Andrić collega uomini e cose: sulla traduzione di Andrić in Italia. Comunicare letterature lingue. Istituto Trentino di Cultura. Bologna, Il Mulino 2003; Diego Zandel, Invito alla lettura di Ivo Andrić. Milano, Mursia 1981; Lazarević Di Giacomo, Persida, I romanzi-cronache di Ivo Andrić. Pescara, Campus 2000; AA.vv, Ivo Andric, scrittore e diplomatico europeo. Trieste, Comunicarte 2010; Radovan Popović, Ivo Andrić, Comunicarte Edizioni, Trieste 2010. За више података в. и Клевернић и др. (2011).

${ }^{5}$ Уп. Јањић (2015), 
Андрића на италијански представља нарочито тежак задатак” јер „његова проза има смирени ритам, неопходан за излагање, без узвика и падова, чији ход стално остаје валовит и умерен, без оштрина, и користи посебна својства акцената српско-хрватског језика”. Одмах затим Секви напомиње како ,jе скоро немогуће репродуковати ритам који Андрић даје својој прози".

Наш осврт на италијанске преводе Андрићевих дела обухватиће једну појаву која можда делује као детаљ, али сматрамо да је релевантна када је реч о преношењу Андрићевог стила ${ }^{6}$ на италијански језик. Анализираћемо, наиме, како је Андрићев презент преношен на италијански језик; у анализи ћемо се у ослонити на текст романа На Дрини ћуприја и на италијанске преводе тог дела7. Уочили смо, наиме, да на неким местима Андрићев презент није доследно превођен његовим италијанским еквивалентним временом, упркос чињеници да презент у оба језика има готово истоветне функције. Он, у односу на перфекат или аорист, посебно истиче радњу, збивање или стање, приближавајући их читаоцу на емотивном и психолошком плану. Презент представља ефикасно стилско средство српске прозе, нарочито када се он изненадно употреби у тексту у коме је доминантно време излагања неко од прошлих времена (то je, углавном, перфекат). Ликови или збивања описани презентом извлаче се у крупни план; наглашавају се њихово психолошко стање и деловање; уз то, презент истиче драматичност описаних ситуација или догађаја. Друга српска времена која се употребљавају као доминантни облици у књижевној прози не могу да постигну поменути ефекат истицања и готово филмски прелаз са широког плана на крупни кадар. Употребом презента аутор привлачи читаочеву пажњу; њиме исказане радње или стања позивају публику да се дубље саживи с ликовима и с описаним ситуацијама. Осмишљена употреба презента представља препознатљиво стилско средство које Андрић примењује како у ширим целинама, тако и у краћим одломцима, па чак и изоловано, ограничавајући понекада овај поступак на само један или два глагола. И италијански презент поседује сличан стилски потенцијал и има сличне функције: ипак, како ћемо видети ниже, постоје одређена ограничења због којих у преводу на италијански језик често није могуће сачувати Андрићев презент и, заједно с њим, конотативне димензије које ово време уноси у текст.

Када је реч о синтакси презента, његове функције су детаљно описане у граматикама оба језика. Употреба презента у српском језику приказана је детаљно код Танасића (1996) и Пипера и др. (2005) - с тиме да је у овом последњем извору аутор одељка о презенту (стр. 352-390) управо Срето Танасић. За италијански језик детаљан опис употребе презента може се наћи

${ }^{6}$ За детаљну анализу језика Иве Андрића и, посебно, за употребу презента уп. Станојчић (1967 : 242-255).

${ }^{7}$ Роман На Дрини ћуприја преведен је два пута: 1962. године (аутор: Бруно Мериђи) и 2001. године (аутор: Дуња Бадњевић). 
код Бертинета (1986) и у Великој граматищи италијанског језика, у којој је поменути аутор написао поглавље о синтакси глагола ${ }^{8}$. Ограничићемо се на констатацију да се увидом у поменуте студије српског језика и у граматике италијанског језика ${ }^{9}$ уочава да се функције презента у оба језика готово у потпуности подударају. Овај податак наводи на претпоставку да српски презент не би требало да представља нарочит традуктолошки проблем за Италијане. Одиста, недоумице не постоје у оним случајевима када српски презент стоји у зависној реченици: због правила о слагању времена ${ }^{10}$ таквом презенту по правилу кореспондира италијански имперфект, барем када је реч о књижевној прози. У наредним примерима из романа На Дрини ћуприја, које наводи Танасић (1996), презент се налази у зависним реченицама и италијански имперфект је његов еквивалент: такво решење примењено је у оба превода Андрићевог романа. Због истоветности преводилачких решења и због простора овде нећемо навести текст италијанских превода; број после процентом изражене локације примера ${ }^{11}$ упућује на страницу Танасићеве студије:

[1] Тада је приметио да се на скелама и по обали пале и крећу светлости $(10 \%, 124)$

[2] Стога је свима изгледао сувише јадан и неугледан за дело због којег га воде на губилиште $(12,8 \%, 128)$

[3] Рекли су јој, или више покретима објаснили, да су њена деца однесена у колибу, тамо где Турци граде ћуприју $(11 \%, 128)$

[4] За време летњих суша, које често упропасте целу жетву, поп Јован је редовно узалуд изводио литију $(14,4 \%, 111)$

И наредни примери преузети су из Танасићеве студије (Танасић 1996): сада је садашње време у независној реченици; описују се стања и збивања у прошлости, а у оба превода романа На Дрини ћуприја употребљен је ита-

${ }^{8}$ Renzi-Salvi (yp.) (1991). Grande grammatica italiana di consultazione. Vol. II. Bologna, Il Mulino, I поглавље. Прво поглавље другог тома ове граматике заправо јесте сажетак обимне Бертинетове студије из 1986. године.

9 За италијански језик види и Бертинето (2003 : 65-87), Морети-Орвието (1984: 13-19), Модерц (2015 : 308-311).

${ }^{10}$ Уп. Модерц (2015), поглавље 7.8.1.10. У италијанском језику није препоручљива употреба презента у зависној реченици уколико је глагол у управној реченици у прошлом времену.

${ }^{11}$ Сви примери у овом раду преузети су из романа На Дрини ћуприја. Податак о локацији примера дат је у процентима јер смо истраживање вршили на дигитализованим и паралелизованим текстовима оригинала и превода. Процентна вредност се добија тако што се број странице у електронском документу на којој се налази пример подели с укупним бројем страница текста (без предговора и поговора - уколико они нису из пера самог писца и нису саставни део преведеног текста). Тако добијени број помножи се са 100. До странице у неком од штампаних издања долази се тако што се укупан број страница књиге подели са 100 и помножи с процентном вредношћу. Овакво бележење места које пример заузима у тексту применљиво је на сва папирна издања, независно од пагинације. 
лијански презент (и овде ћемо, због истоветности преводилачких решења, изоставити текстове превода):

[5] Народ лако измишља приче и брзо их шири $(10,8 \%, 35)$

[6] Ту се, на ћупријској огради, излажу на продају прве трешње и бостан $(2,1 \%, 52)$

[7] И све се сврши на томе $(12,8 \%, 53)$

[8] Тада нема задржавања на отвореним терасама $(2,55 \%, 55)$

[9] Људи који сами не раде ништа и не предузимају ништа у животу лако губее стрпљење и падају у погрешку кад суде о туђем раду $(10,5 \%, 92)$

[10] Јао, премрем кад помислим! $(9,3 \%, 94)$

[11] Удри одмах, јер тај има и на себи и у бисагама $(2,8 \%, 107)$

[12] Такво једно проширење настаје и овде, код Вишеграда, на месту где Дрина избија из дубоког и уског теснаца $(0,1 \%, 110)$

[13] А код укопа, они који носе покојника спусте га малко да се одморе $(2,4 \%, 110)$

[14] Кунем ти се животом и вером којом се не куне лако $(60 \%, 110)$

[15] У једној пространој и сувој појати гори ватра на средини, управо догорева, јер је од ње остало само још жеравица која тиња у полумрачној просторији $(5,1 \%, 156)$

Презент у директном обраћању (примери [10], [11], [14]) увек се преводи италијанским презентом. У случајевима где српски презент поприма општу, гномску или ванвременску вредност (примери [5] и [9]) такође се употребљава италијански презент. И у примерима који упућују на хабитуалне радње ([6], [8], [13]) и на местима где се описују стална или привремена стања (редом: примери [12] и [15] ${ }^{12}$ ) еквивалент српског садашњег времена је италијански презент. Пример [7] може се тумачити као закључни коментар аутора; он се може тумачити као пишчево обраћање читаоцу. Из наведених примера можемо закључити да и у независној реченици италијански презент може да буде еквивалент српског презента. Ипак, на основу увида у друга места романа и у начине на које су се преводиоци односили према српском презенту, констатовали смо да еквивалентност презент : presente није доследно примењивана у многим случајевима где је српско садашње време у независној реченици. Штавише, српски презент у роману На Дрини ћуприја превођен је имперфектом и у оним случајевима када за такав поступак заправо не постоје синтаксички разлози (као што је случај са слагањем времена). Још већу недоумицу изазивају они Андрићеви презенти за које преводиоци дају различита решења, односно где један употребљава презент а други неко од италијанских прошлих времена.

\footnotetext{
${ }^{12}$ Ова два примера садрже и зависну месну реченицу [12] и зависно-односну реченицу [15]: у преводу, у управној реченици је презент, те се и у зависним реченицама може употребити презент.
} 
У наредним примерима (који су такође преузети из Танасићеве студије) види се како се преводиоци Бруно Мериђи и Дуња Бадњевић различито односе према Андрићевом презенту (скраћенице уз италијанске глаголске облике су: през - презент/presente, имп - имперфект/imperfetto, прости перф. - прости перфект/passato remoto):

[16] На улазу у чаршију (...) има један зараванак на коме се досада средом држао сточни пазар $(16,7 \%, 111)$

[16a] All'ingresso della piazza (...) si trova ${ }_{\text {през }}$ una piccola altura nel cui centro, fino ad allora, si teneva il mercato del bestiame. (Мериђи)

[16б] All'entrata della čaršija (...), vi era mercoledì si teneva il mercato del bestiame. (Бадњевић)

[17] Први људи из чаршије, пошто су сместили чељад по кућама, (...), седе, окупљени у великој приземној соби $(13,2 \%, 154)$

[17a] Le persone più importanti del mercato, (...), seggono ${ }_{\text {през }}$ raccolte nella grande stanza a pianterreno dell'abitazione di Hadgi Ristan. (Мериђи)

[17б] I notabili della čaršija, (...), si raccolsero a pianterreno nella casa di hadži-Ristan. (Бадњевић)

[18] И по појатама горе ватре крај којих се суши народ који није могао да стане у куће $(13,2 \%, 156)$

[18a] E nelle casupole ardono $_{\text {през }}$ i fuochi, accanto ai quali si asciugano coloro che non hanno potuto restarsene in casa loro. (Мериђи)

[18б] Anche nelle stalle erano vano $_{\text {имп }}$ coloro che non avevano trovato posto nelle case. (Бадњевић)

Откуд ове разлике између једног и другог превода? Одговор нам не могу пружити изоловани примери [16]-[18] већ увид у шири контекст коме ови примери припадају. Такав приступ у тумачењу морамо да применимо и на примере [6], [8] и [13] који, према процентној вредности којом је изражена њихова локација, очигледно припадају истом, дужем сегменту излагања ${ }^{13} . \mathrm{y}$ оригиналу поменути сегмент је готово у целости написан у презенту. Увидом у италијанске преводе романа На Дрини ћуприја установили смо да се српски презент који припада дужим целинама излагања обично преводи италијанским презентом; тако је и у три наведена примера ([6]-[8]-[13]), који припадају, како је већ речено, истој целини. Иста констатација важи и за пример [12], који се налази на самом почетку романа, у уводном делу, где је презент доминантно

${ }^{13}$ Употребљавамо термин „излагање” како бисмо сачували два кључна термина за италијанистичку наратологију (а чини се, и за романске језике уопште): наращија (приповедање) и дескрипиија (описивање). Помоћу ових техничких термина могуће је описати устројство италијанског прозног текста, што ћемо покушати да учинимо у наставку текста. 
време u ширем контексту; исто важи и за пример [15]. Еквиваленти ових презента су, у оба превода, италијански презенти.

Може се с разлогом претпоставити, дакле, да ће дужи сегменти излагања на српском, с презентом као доминантним временом, бити преведени италијанским презентом. Супротно овоме, у сегментима излагања где се српски презент јавља спорадично или изоловано, италијански презент се ређе јавља као његов еквивалент. Тада се такво презентско „острво” из српског текста преводи оним прошлим временом које је доминантно у околном контексту. Наредни пример илуструје како се у Андрићевом тексту презент може јавити изненадно, творећи презентско „острво” коме претходи и следи текст где је доминантно време перфекат. У преводима се види да његов еквивалент није италијански презент већ имперфект:

[19] Samo savijaju cigare i pale jednu o drugu. (44,3\%)

[19a] Soltanto si arrotolavano имп $_{\text {le sigarette e se le accendevano }}$ имп, l'una dopo l'altra. (Мериђи)

[19б] Si limitavano l'altra. (Бадњевић)

На основу ових запажања и на основу увида у друге књижевне преводе наших писаца можемо претпоставити да постоји корелација између дужине сегмента у коме је у српском оригиналу доминантно време презент и вероватноће да ће у преводу на италијански језик његов еквивалент бити presente. И, обрнуто, што је сегмент с презентом краћи, то је мања вероватноћа да ће у преводу бити употребљен presente.

Ипак, када је реч о књижевним преводима на италијански језик, ствари нису једнозначне. Превођење презента није условљено искључиво величином сегмента у коме је ово време доминантно. Ову тврдњу поткрепићемо примером који садржи дужи презентски сегмент; начин на који је презент преведен на италијански побија управо предложену радну хипотезу о директној корелацији између дужине презентског сегмента оригинала и вероватноће да ће у преводу његов еквивалент бити презент. Послужићемо се одломком из романа На Дрини ћуприја у коме се описује градња моста на Дрини. На овом месту уочава се да се преводиоци опходе готово произвољно према Андрићевом презенту и према конотацијама које српско садашње време производи. Одломак који је привукао нашу пажњу има укупно 1.568 речи; од тога, сегмент у ком је презент доминантно време броји 1.439 речи: због дужине одломка нисмо у могућности да га на овом месту репродукујемо у целини. Овај сегмент смо поделили на три подсегмента у зависности од тога који су еквиваленти презента примењени у једном и у другом преводу. На овај презентски сегмент од укупно 1.439 речи надовезује се још један подсегмент (четврти, с укупно 129 речи, што чини укупно 1.568 речи) у коме се Андрић враћа на 
перфекат као доминантно време; ово место је занимљиво јер у њему један преводилац наставља с употребом италијанског презента, настављајући на тај начин претходни презентски подсегмент у свом преводу. Тако се у једној од две италијанске верзије ствара презентска целина која не постоји у оригиналном тексту, односно - а ово сматрамо важним за рецепцију књижевног дела - истичу се радње или стања која у српском тексту нису истакнута ни на емотивном, ни на психолошком плану.

Први подсегмент има 647 речи; он почиње речима:

[20] Путеви су испроваљивани од претоварених кола. (5,71\%) и завршава се:

[21] (...) али сејмени одмах узму из те куће таоце, често и жене, уместо одбеглих младића. $(6,31 \%)$

У одговарајућем италијанском подсегменту ниједан од преводилаца не употребљава презент као еквивалент српског садашњег времена. Обоје настављају с употребом прошлих времена држећи се доминантног времена које су применили за превођење ранијег, овоме претходног сегмента Андрићевог текста (у коме и Андрић употребљава перфект као доминантно време). Употребом презента Андрић у првом подсегменту постиже ефекат драматичности и уживљавања у патње кулучара ангажованих на градњи моста; преводиоци, међутим, избором да ову целину преведу прошлим временима затамњују наглашену емотивну и психолошку димензију текста. У оба превода излагање остаје дистанцирано, објективно, лишено емпатије и уживљавања у патње и страдање градитеља-кулучара. Тек у другом подсегменту један преводилац, Мериђи, приклања се Андрићевим интенцијама и у свом тексту прелази на презент; други преводилац, Дуња Бадњевић, наставља с употребом италијанских прошлих времена, приклањајући се преводилачком решењу из почетног подсегмента. Други подсегмент има 347 речи и почиње речима:

[22] Ово је трећа јесен како народ кулучи на мосту (...) (6,31\%) и завршава се:

[23] Али не спавају сви; умеју и они да бдију, за свој рачун и на свој начин. $(6,61 \%)$

Тек у трећем подсегменту, који броји 445 речи, и Бадњевићева се опредељује за италијански презент као еквивалент српског садашњег времена и почиње да прати не само фактографију већ и репрокукује драматику којом Андрић боји своје излагање. Трећи подсегмент почиње речима:

[24] У једној пространој и сувој појати гори ватра на средини, управо догорева (...) $(6,61 \%)$ 
и завршава се:

[25] (...) кулучари, занесени и неосетљиви за све остало, прате песму као сопствену, лепшу и светлију судбину. (7,06\%)

У наставку, у поменутом четвртом подсегменту (од 129 речи), Андрић прекида с употребом презента и враћа се на излагање у коме су доминантна прошла времена, односно у коме доминира објективан и дистанциран став у односу на радњу романа. Мериђи у свом преводу реагује на ову промену и прелази на објективан став у приповедању тако што поново употребљава италијанска прошла времена (и на тај начин постиже објективно и дистанцирано излагање). Изненађујуће, без видног разлога, на овом месту Дуња Бадњевић наставља с употребом презента. Четврти подсегмент почиње речима:

[24] Међу толиким кулучарима сељацима био је и неки Радисав (...) $(7,06 \%)$

и завршава се:

[25] Његово је казивање било углавном овакво: (...) (7,21\%)

У четвртом, последњем подсегменту, Дуња Бадњевић као да жели да компензује опредељење да занемари Андрићев презент у првом и другом подсегменту свог превода; она сада шири употребу италијанског презента и на четврти подсегмент, иако за такав поступак не постоји никакав синтаксички, књижевни или какав други разлог. Поступајући на овај начин Дуња Бадњевић уноси драматичност и истиче психолошко-емотивну димензију радњи и стања које Андрић пак, употребом перфекта, приказује неутрално, објективно, дистанцирано.

Изражено бројкама, Бруно Мериђи у овом дужем сегменту романа $\mathrm{Ha}$ Дрини ћуприја преводи Андрићево садашње време италијанским презентом у 55\% текста, док Дуња Бадњевић поступа тако у $31 \%$ текста (не рачунајући четврти подсегмент, који чини додатних $9 \%$ у односу на претходна три подсегмента). Оваква колебања у превођењу овог места учинила су нам се необичним, те смо консултовали још два превода на стране језике. У енглеском преводу ${ }^{14}$ романа На Дрини ћуприја анализирани одломак у потпуности је преведен прошлим временима (изузимајући, наравно, места која садрже директан говор): губитак драматике и емотивно-психолошке димензије Андрићевог презента у енглеском језику је потпун доприноси осиромашењу изворног књижевног

${ }^{14}$ The Bridge On The Drina. Превео Ловет Ф. Едвардс (Lovett F. Edwards). Издавач: George Allen \& Unwin, Лондон 1959. Едвардсов превод је више пута понављан; најновије издање, према каталогу Народне библиотеке Србије, је из 2015. године. 
текста. Превод на шпански језик ${ }^{15}$, напротив, врло је прецизан када је реч о садашњем времену: у целом анализираном одломку, наиме, ово глаголско време је доследно превођено шпанским презентом. Овакво преводилачко решење показује да је овај преводилачки двојац обратио посебну пажњу пажљивом преношењу Андрићевих готово спонтаних и неосетних, а у књижевно-стилском погледу важних прелаза с објективно обојеног на субјективно и психолошки маркирано излагање. Прецизност превода на шпански језик може да изазове недоумице у вези с италијанским преводима, будући да су ова два романска језика структурно врло слична не само када је реч о употреби презента. Сматрамо да разлоге за овакво одступање треба тражити у књижевним моделима на основу којих су Мериђи и Бадњевићева структурирали текстове својих превода. Они су се у свом раду очигледно ослонили на нешто старије италијанске књижевне моделе, у којима је алтернација прошло време : презент представљала спорадичну, ограничену појаву. У савременој италијанској прози дошло је до одређених синтаксичких помака и презент се сада слободније прожима кроз текст (кроз коментаре аутора, уживљавање у радњу, психолошко и емотивно истицање одређених места итд.); један преводилац који је показао изванредну осетљивост у односу према овој промени у италијанском језику и у односу према Андрићевом презенту био је слависта Лионело Костантини, чији превод Проклете авлије ${ }^{16}$ остаје - сматрамо - узорит у многим елементима, а нарочито када је реч о теми која нас овде интересује, преношење на италијански конотативних вредности српског презента.

Изостављање презента у наведеном одломку на италијански може се тумачити као резултат процеса структурирања италијанског текста и одговора на захтев да превод задовољи један од основних критеријума текстуалности - кохерентност. У италијанском језику кохерентност текста обезбеђује се језичким инструментима који у српском језику немају такву функцију; из ове суштинске разлике проистичу, делом, преводилачка колебања која смо уочили. Главни инструмент који доприноси кохерентности италијанског књижевног текста су глаголска времена: њихова функција није сведена на обавештавање о темпоралним односима између радњи и стања. Она преносе још две значајне информације: прва (свакако не по важности) јесте да глаголска времена одражавају ауторов приступ предмету излагања. У италијанском тексту излагање

${ }^{15}$ Un puente sobre el Drina. Превели Луиса Фернанда Гаридо Рамос (Luisa Fernanda Garrido Ramos) и Тихомир Пиштелек. Издавач: RBA 2010.

${ }^{16}$ La corte del diavolo. Adelphi, Milano 1992. Иста оцена се не може изрећи за први превод, Il cortile maledetto (Bompiani, Milano 1962), Јоланде Маркјори, која је готово систематским изостављањем презента из свог превода приближила Андрићев текст фактографском извештавању. Међутим ова појава, примењивање традиционалних језичких иструмената модела приповедања, погађала је већину књижевних превода савремених дела, барем до седамдесетих година прошлог века. Уп. Модерц-Барби (у штампи) и случај превода Бредберијевог романа Фаренхајт 451 на италијански језик. 
може бити организовано као нарација (приповедање) или као дескрипција (описивање). Ова два приступа у излагању резултат су употребе глаголских времена. Перфективна времена су доминантна у наративном приступу (passato remoto, passato prossimo, trapassato prossimo), док је дескриптивни приступ обележен imperfettom (или, још, садашњим временом) као доминантним временом. Важно је истаћи да се у италијанској прози (па и у језику уопште) поступци нарације и дескрипције, онако како су овде дефинисани, не могу слободно комбиновати. Сваки прелаз са приступа нарације на приступ дескрипције (и обратно) мора да буде мотивисан, читаоцу/говорнику прихватљив и не сме да угрози кохерентност излагања, односно да поремети унутрашњу логику текста. Сегменти излагања с наративним, односно с дескриптивним приступом су, самим тиме, тенденцијално хомогени када је реч о присуству доминантног глаголског времена. Из реченог произлази да у италијанском тексту није уобичајено слободно смењивање прошлог времена (мислимо на доминантно време нарације - passato remoto) и презента: ова констатација представља део могућег објашњења за недоумице и варијације које су уочене у преводима цитираног одломка романа На Дрини ћуприја. Друга информација коју садржи доминантно време у сваком сегменту излагања тиче се става који приповедач заузима у односу на предмет казивања. У италијанској прози разликују се два става: дистанцирани, у којем приповедач заузима објективан, суздржан однос према садржају излагања (времена passato remoto и trapassato prossimo исказују такав став приповедача), и психолошко-емотивно ангажовани став, у којем се приповедач уживљава у садржај излагања и приказује га као актуелан, значајан, драматичан (о таквом ставу обавештавају presente и passato prossimo).

У српском језику наведене опозиције као елементи структурирања књижевног текста (наративни : дескриптивни приступ, објективни : субјективни став приповедача) углавном се не реализују кроз специјализоване језичке инструменте. Један изузетак јесте употреба наративног презента, који има функцију да сигнализира - како смо видели у досадашњем излагању - актуелност, односно емотивну и психолошку ангажованост приповедача у односу на предмет излагања. У српском прелаз с једног става приповедача на други, са субјективног на објективни, не подлеже посебним рестрикцијама. Оба елемента двеју опозиција у српском језику могу се смењивати не угрожавајући - за разлику од италијанског језика - критеријуме текстуалности: уп. пример [19], где се изолованим презентима истичу рутинске радње - савијање дувана и паљење цигарете - и наглашава напетост, нестрпљење ликова обузетих карташком игром ${ }^{17}$.

${ }^{17}$ Ова два презента не стварају у српском тексту искок који ремети кохезију овог места с претходним и потоњим текстом. Управо речено не важи за италијански језик и за принципе структурирања текста: на овом месту управо употреба имперфекта у оба превода обезбеђује кохерентност текста. 
Већа слобода комбиновања српских глаголских времена дозвољава еластичније прибегавање стилским ефектима које она производе, при чему кохерентност књижевног текста остаје непоремећена. Пажљивом употребом времена може да се успори ритам излагања (перфектом или, мада данас ређе, плусквамперфектом), или да се убрза (аористом), или да се с објективног, неутралног и дистанцираног става у односу на предмет излагања (употребом стилски немаркираног времена, нпр. перфекта) без нарочитих ограничења и условљавања пређе на психолошки и емотивно маркиран став (употребом презента). Узгредно, додатну контрастивну потешкоћу представља и чињеница да у српском тексту перфекти свршених и перфекти несвршених глагола могу да стоје једни уз друге, не утичући на кохерентност текста. У италијанском језику видске опозиције имају секундарну улогу и текст се структурира према опозицијама нарација : дескрипција и објективно : субјективно, утемељеним на употреби специјализованих глаголских времена. Из реченог произлази да се и видске опозиције присутне у српском тексту често морају занемарити ради очувања текстуалне кохерентности италијанског превода ${ }^{18}$. О овом проблему уп. Модерц (1996) и Миклич (1981). Мада овај последњи извор обрађује словеначко-италијанску контрастивну проблематику, део закључака Тјаше Миклич може се применити и на српско-италијанску контрастивну проблематику.

Нека врста потврде да српска глаголска времена немају уочљиву улогу у структурирању кохерентног књижевног текста јесте чињеница да студија Харалда Вајнриха ${ }^{19}$ о функцијама глаголских времена у тексту није преведена на српски језик, вероватно зато што наш језик не може да понуди одговарајуће преводе или адаптације за примере које у својој студији наводи немачки аутор. С друге стране, ово дело преведено је на италијански, мада морамо напоменути да је у италијанистичким студијама до сада много већа пажња посвећивана синтакси глагола и његовим аспектуалним и акционалним особинама а приметно мање интересовање будило је питање функција времена у тексту и проблем текстуалности уопште ${ }^{20}$.

${ }^{18}$ Илустроваћемо проблем једним примером из наставе превођења за италијанисте: „Када је потонуо велики прекоокеански брод, све су новине писале о томе и дале велики значај догађају”. Несвршени перфект „писале” припада целини излагања коју одређују свршени перфекти „(је) потонула” и „(су) дале”: због њих се ова целина смешта у наративни приступ и сва три глаголска облика морају се превести хомогено, истим обликом (passato remoto, нпр.). У супротном, у овом кратком сегменту стајали би напоредо, мимо било каквог критеријума текстуалности, један имперфект (,scrivevano”) и два перфективна времена („,naufragò”, „diedero”).

${ }^{19}$ Harald Weinrich. Tempus. Besprochene und erzählte Welt. Universität Münster, 1964. Италијански језик има могућност да одговарајућим примерима подржи Вајнрихово излагање те је студија преведена на овај језик (уп. Библиографију). Одломак из Вајнрихове студије преведен је у Крамарић (1989).

${ }^{20}$ Текстуалном лингвистиком се бавила, на пример, Марија Елизабет Конте (Condizioni di coerenza. Ricerche di linguistica testuale. Edizioni dell‘Orso 1988). Сам Бертинето се, после те- 
Функције италијанских прошлих времена у образовању кохерентних текстуалних целина у којима доминирају или нарација или дескрипција (у односу узајамног искључивања), односно објективни или субјективни став приповедача (такође у односу узајамног искључивања) постављају се у први план приликом превођења књижевног текста на италијански. Преводиочево умеће огледа се у способности да гради текст превода полазећи од српског текста, у коме се поменуте опозиције не маркирају већ постају, најчешће - у недостатку јасних језичких знакова - предмет индивидуалног тумачења. Уз ово, јаз (темпорални, функционални, стилистички) између перфекта и презента у српском није тако упадљив као јаз између еквивалентих италијанских времена, простог перфекта и презента. Српски пар времена (перфект : презент) релативно се слободно алтернира у тексту, не реметећи његову кохерентност. У италијанском се дешава управо супротно, алтернација простог перфекта и презента производи утисак наглог скока, тешко објашњивог прелаза са дистанцираног на субјективно обојено излагање. Преводилац мора да, у недостатку јасних језичких знакова, подвргне српски текст фином читању, да препозна она места где аутор мења приступ излагању или став према предмету излагања; преводилац мора да претпостави постојање таквих места или чак да их и сам установи, радећи више у корист кохерентности текста превода, његове саобразности с начелима структурирања текста која важе за италијански језик и његове потпуне прихватљивости за италијанског читаоца него што поступа у корист доследног очувања оригиналног текста. Управо захтев да текст превода буде кохерентан објашњава употребу имперфекта и других прошлих времена у примерима [1]-[4]: италијански презент би на овим местима прекинуо претходно заузет објективни и дистанцирани став у односу на предмет излагања. И управо пресудна улога коју преводилац има у процесу структурирања еквивалентног италијанског текста може да осветли зашто су Мериђи и Бадњевићева поступали недоследно и свако на своји начин у односу на шири одломак обухваћен примерима [20] и [25]. Овде је Андрићев субјективни став, који се препознаје у употреби презента, у мањој или већој мери занемарен због ауторске одлуке преводилаца да другачије организују текстуалне целине својих превода, ослањајући се на своју процену пре него на интенције аутора српског текста. Оставши на дистанцираном и објективном ставу у односу на предмет излагања и наставивши да употребљавају прости перфект (и, уз њега, имперфект) као доминантно време, преводиоци не следе Андрићев прелаз на субјективно обојено излагање. Они чак интегришу први подсегмент (а Дуња Бадњевић и други) анализираног одломка с претходном целином, у којој Андрић има дистанциран став у односу на радњу и у којој је доминантно време емотивно и психолошки неутрални (или: дистанцирани

мељног изучавања италијанског глаголског вида и значењског глаголског лика (Бертинето 1986), осврнуо на функције глаголских времена у тексту (Бертинето 2003). 
- мада овакво одсечно одређење важи првенствено за италијански језик и само је делимично применљиво на српски) перфекат. Таква одлука преводилаца не ремети кохерентност италијанског текста; суштински, не ремети је ни одлука Дуње Бадњевић да настави с употребом презента и у четвртом подсегменту, ширећи опсег субјективног излагања и на део текста где Андрић заузима објективан став у односу на излагање. Ипак, оваква измена емотивно-психолошке топологије Андрићевог изворног текста делује као произвољна и немотивисана. Не постоје препреке да у одговарајућем италијанском тексту presente не буде стални еквивалент садашњег времена (уп. горе, осврт на шпански превод), али Бруно Мериђи и Дуња Бадњевић су се определили да структурирају италијански текст другачије. Поступајући на описани начин преводиоци су уклонили из италијанског текста садашње време као важан елемент Андрићевог стила којим се подстиче читаочево уживљавање у радњу, његово удубљивање у психолошки и емотивни свет ликова и његова емпатична реакција. Пажљивом употребом овог времена Андрић истиче релевантне црте описаних личности, или пак наглашава драматику описаних ситуација, док у италијанском тексту читалац остаје ускраћен за емотивна и психолошка нијансирања ликова и ситуација која је, са својим разлозима, одредио Андрић.

За краће текстове као што су приповетке изостављање презента у преводу и произвољно опредељивање за објективан став приповедача може имати веће последице када је реч о рецепцији такве књижевне форме: она због своје мање дужине оставља мање простора за евентуални поступак компензације (како чини Дуња Бадњевић у четвртом подсегменту), а сама приповетка може остати лишена можда и јединог тренутка емотивно-психолошког приближавања лику или описаној ситуацији. У текстовима веће дужине као што је роман На Дрини ћуприја локални губитак субјективног освртања на предмет радње мање је опажљив и лакше се компензује другим местима на којима је субјективни став аутора сачуван кроз употребу италијанског презента. Упркос оваквој преводилачкој слободи, сматрамо да преводиоци на италијански немају разлога да у текстовима својих превода не пренесу верно и доследно ауторов психолошки и емотивни фокус, без обзира на дужину оригиналног текста и на већу или мању могућност компензовања: савремена италијанска проза је, како смо раније поменули, еластичнија по питању употребе презента. Наша опажања, у том смислу, попримају вредност констатације када је реч о Мериђијевом преводу (из 1960. године), насталом у време и под утицајем крућих - у формалном погледу - наративних структура у италијанској књижевности; у случају превода Дуње Бадњевић (2001. година) наша запажања могу се већ схватити као критика, будући да су до времена настанка и објављивања њеног превода романа На Дрини ћуприја поменуте наративне структуре италијанске прозе постале еластичније и могле су да прихвате слободнију употребу италијанског презента. Уз то, не треба заборавити ипак - чини се - незаобилазан 
утицај традуктолошког примера и узора из осамдесетих година прошлог века, поменутог Лионела Костантинија и његове преводе српских књижевних дела на италијански језик, који се одликују пажљивијим поступањем и чувањем конотативних вредности српског презента.

С обзиром на управо изнесена размишљања, преостаје нам да закључимо да наш осврт на употребу презента у преводима Андрићевог романа На Дрини ћуприја отвара простор за промишљања која су ближа књижевној критици и наратологији него лингвистичкој анализи. Отвара се питање какве последице могу имати поменуте недоследности у преношењу стилистичког потенцијала Андрићевог садашњег времена на рецепцију књижевног дела, колико се оваквим поступањем мења Андрићева ауторска интенција, колико трпи његова тачка гледања као приповедача; затим, колико бива измењена рецепција његових ликова, мисли, осећања, коментара када су они у преводу приказани из обрнуте перспективе у односу на изворну пишчеву намеру. На ова питања не можемо да дамо коначан одговор; она заслужују темељнији приступ и дубљу анализу.

\section{КОРПУС}

Андрић, Иво. На Дрини ћуприја. Београд: Лагуна 2015.

Andrić, Ivo. Il ponte sulla Drina. Milano: Mondadori 2001. (превела Дуња Бадњевоић).

Andrić, Ivo. Il ponte sulla Drina. Milano: Mondadori 1962. (превео Бруно Мериђи).

\section{ЛИТЕРАТУРА}

Бертинето 1986: P. M. Bertinetto, Tempo, aspetto e azione nel verbo italiano. Accademia della Crusca. Firenze.

Бертинето 2003: Р. M. Bertinetto, Tempi verbali e narrativa italiana dell 'Otto/ Novecento. Edizioni dell'Orso. Alessandria.

Вајнрих 2004: H. Weinrich, Tempus. Le funzioni dei tempi nel testo. Il Mulino, Bologna.

Јањић 2015: D. Janjić, Impressioni italiane di Ivo Andrić. Paralellismi linguistici, letterari e culturali. 55 anni di studi italiani (13-14 settembre 2014). Skopje 2015, 633-640. 
Клевернић 2011: Љ. Клевернић (координатор) и др., Библиографија Иве Андpuћa: 1911-2011. Главни уредник Миро Вуксановић. Задужбина Иве Андрића, САНУ, Библиотека Матице српске.

Крамарић 1989: Z. Kramarić, Uvod u naratologiju [zbornik tekstova]. Osijek. Revija Radničko sveučilište „Božidar Maslarić”.

Лукези 1971: V. Lucchesi, Fra grammatica e vocabolario. Studi sull 'aspetto del verbo italiano. Studi di grammatica italiana 1, Accademia della Crusca, Firenze, 179-270.

Миклич 1981: T. Miklič, Kriteriji izbire med perfektom in imperfektom v primerjavi s kriteriji izbire med dovršniki in nedovršniki. Italijansko-slovenska kontrastivna analiza. Filozofska fakulteta Univerze Edvarda Kardelja, Ljubljana.

Модерц 1996: С. Модерц, Превођење српских прошлих времена на италијански. Магистарски рад. Филолошки факултет, Београд.

Модерц 2014: S. Moderc, I testi letterari paralleli e la valutazione della traduzione: il caso dell interpunzione. Nasleđe 29, 2014. Filološko-umetnički fakultet Kragujevac, 203-215

Модерц 2015: S. Moderc, Gramatika italijanskogjezika. Morfologija s elementima sintakse. III izdanje. Luna crescens, Beograd.

Пипер 2005: П. Пипер и др., Синтакса савременога српског језика. Проста реченииа. Институт за српски језик САНУ, Београдска књига, Матица српска, Београд.

Ракић 1998: Б. Ракић, Енглески превод На Дрини ћуприје. Свеске Задужбине Иве Андрића. Година XVII, свеска 14.

Савић 1984: С. Савић, Из прагматике глаголских облика у српскохрватском језику: употреба презента и перфекта у приповедању. Научни састанак слависта у Вукове дане. Свеска 14/2. Београд-Нови Сад-Приштина-Тршић 11-16. IX 1984.

Секви 1962: Е. Секви, Андрић, Италија и Италијани. У: Иво Андрић. Институт за теорију књижевности и уметности. Београд 1962, 287-299.

Станојевић 2010: В. Станојевић, О употреби глаголских времена у Ћопићевој причи Поход на мјесеи и у њеном преводу на франиуски. Научни састанак слависта у Вукове дане. Свеска 40/1. Београд 08-11. IX 2010.

Станојчић 1967: С. Ж. Станојчић, Језик и стил Ива Андрића (Функиије синонимских односа). Београд: Филолошки факултет Универзитета у Београду. Монографије. Књига XI 
Стевановић 1991: М. Стевановић, Савремени српскохрватски језик II. Пето издање. Београд: Научна књига.

Танасић 1996: С. Танасић, ІІрезент у савременом српском језику. Институт за српски језик САНУ, Београд.

Терић 2009: G. Terić, Sintaksa italianskog jezika. Beograd, Filološki fakultet.

Чоти 2001-2002: F. Ciotti, Tempi verbali e struttura narrativa: un modello di analisi computazionale del testo narrativo. In Mordenti R. (a c. di), Giuseppe Gigliozzi: La fondazione dell'informatica applicata al testo letterario. Numero monografico di «Testo \& Senso», nn. 4-5, 2001-2002, 123-144.

\section{PRESENT TENSE IN THE NOVEL "THE BRIDGE ON THE DRINA" AND ITS TRANSLATABILITY IN ITALIAN}

\section{Summary}

Translating Andrić's novels into Italian poses a series of problems to the translator; one of them is finding a proper equivalent for Serbian present tense. The versatility of Serbian present tense allows Andrić to shift unexpectedly from objective narration to a more subjective tone just by using this tense. On the other hand, although Italian presente has nearly the same values of Serbian present tense, limitations of textual nature do not allow to reproduce in Italian every single occurrence of Serbian present tense. Hence the latter is often substituted with Italian past tenses, but by doing so the translation loses psychological and emotional connotations that derive from Serbian present tense. The reasons for the loss of present in Italian translations are partly of syntactic nature (especially in subordinate clauses) and partly are determined by the structure of Italian literary text. In some cases the omission of present is a result of translator's autonomy to adopt in her/his text one of the two narrative models/oppositions that are dominant in Italian prose: the subjective $v s$. objective position, or the narrative $v s$. descriptive approach in structuring a narrative text. These models require specialized Italian tenses which are subject to rigid limitations regarding their mutual combinations. Unlike Italian, Serbian text doesn't convey such oppositions and therefore its tenses can be combined in a much more elastic way if compared to Italian text. This structural difference between Italian and Serbian can explain the reasons why the translators of the two versions of Andrić's novel The Bridge On The Drina in some cases were not allowed to use Italian presente. But in some cases, as is shown in this paper, the decision to omit in their translations Italian presente as an equivalent of Andrić's present tense is the result of their personal choices and approach.

Key words: Ivo Andrić, present tense, Serbian, Italian, translation, structure of literary text, distance, objectiveness, psychological-emotional position

Saša G. Moderc, Tijana N. Kukić 